\title{
Towards the Identification of Novel Platelet Receptors: Comparing RNA and Proteome Approaches
}

\author{
Peter Bugert Melanie Ficht Harald Klüter \\ Institute of Transfusion Medicine and Immunology, University of Heidelberg, Faculty of Clinical Medicine, Mannheim, Germany
}

\section{Key Words}

Platelets · Transcriptome · Proteome - Receptors ·

Membrane proteins $\cdot$ Microarray

\section{Summary}

Over the past few years, the new technologies of transcriptomics and proteomics have been applied to platelet research. Whole-genome profiling of the transcriptome using microarray hybridization can be performed with less time and effort compared to proteome investigation. On the other hand, the significance of RNA data may be limited with regard to actual protein expression. This review compares published platelet transcriptome and proteome data in order to identify the number of discrepancies between the two molecular profiles. With a focus on membrane proteins, we wanted to know whether transcriptomic and proteomic studies may contribute to identifying novel platelet proteins.

\section{Introduction}

Blood platelets are anucleated cell fragments derived from megakaryocytes in the bone marrow and represent the most important cellular component in hemostasis. They also play important parts in maintaining the integrity of the blood vessel endothelium, wound healing and tissue regeneration. A large variety of growth factors, cytokines and other effector molecules can be found in the storage granules of platelets

\section{Schlüsselwörter}

Thrombozyten · Transkriptom · Proteom · Rezeptoren

Membranprotein · Mikroarray

\section{Zusammenfassung}

Im Laufe der letzten Jahre wurden moderne Methoden der Transkriptom- und Proteomanalyse auch bei den Blutplättchen angewendet. Die das gesamte Genom umfassende Untersuchung des Transkriptoms kann im Vergleich zur Proteomanalyse mit deutlich geringeren Zeitund Arbeitsaufwand durchgeführt werden. Jedoch könnte es Limitationen der RNA-Daten im Bezug auf die tatsächliche Proteinexpression geben. In diesem Übersichtsartikel werden publizierte Plättchentranskriptomund -proteomdaten verglichen, um das Maß an Abweichungen der beiden molekularen Profile zu ermitteln. Wir haben auch untersucht, inwiefern Transkriptom- bzw. Proteomstudien zur Identifizierung neuer Plättchenproteine beitragen können und haben uns dabei auf Membranproteine konzentriert.

and are released upon activation. Because platelets lack a nucleus, they are believed to have an only limited to no capacity of de novo protein synthesis. Therefore, platelets need to be equipped with all proteins which are either presynthesized in megakarycytes and stored in granules (e.g. P-selectin [1]) or acquired from extracellular sources, such as plasma or other blood cells (e.g. tissue factor [2]). Platelets also contain ribosomal and messenger RNA carried over from megakaryocytes, but the amounts are rather low - about 100,000 times less

\begin{tabular}{ll}
\hline KARGER & ๑ 2006 S. Karger GmbH, Freiburg \\
$\begin{array}{l}\text { Fax +49 76145207 14 } \\
\begin{array}{l}\text { E-mail Information@Karger.de } \\
\text { www.karger.com }\end{array}\end{array}$ & $\begin{array}{l}\text { Accessible online at: } \\
\text { www.karger.com/tmh }\end{array}$ \\
\end{tabular}

Dr. Peter Bugert

Institute of Transfusion Medicine and Immunology

German Red Cross Blood Service of Baden-Württemberg - Hessen gGmbH

Friedrich-Ebert-Straße 107, 68167 Mannheim, Germany

Tel. +49 621 3706-8122, Fax -851

E-mail p.bugert@iti-ma.blutspende.de 
compared to leukocytes. Based on our own experience, approximately $100 \mathrm{ng}$ of purified total RNA can be isolated from $10^{9}$ platelets. A similar amount can be obtained from as little as $10^{4}$ leukocytes. Despite controversial findings concerning the biological activity of gene transcripts in terms of de novo protein synthesis [3-6], it is obvious that transcripts found in platelets are derived from genes that are active in late megakaryopoiesis. The transcriptome represents a useful source of information about the expression state of genes including those that have not yet been considered for platelets. With the introduction of microarray techniques, the complex characterization of cellular transcriptomes evolved to an important approach to investigate physiological and pathophysiological processes. Recently, microarray techniques were applied for mRNA profiling in human platelets of healthy individuals [reviewed in 7]. The importance of the transcriptomic approach in learning about pathomechanisms of platelet disorders was proven by a study of Gnatenko et al. [8] which investigated patients with essential thrombocytemia. It was demonstrated that distinct subtypes of $17 \beta$-hydroxysteroid deoxygenases are active in platelets and that the expression pattern of these enzymes is significantly associated with the platelet disorder.

The understanding of the important role that platelets play not only in hemostasis and atherothrombosis but also in inflammatory and immunological processes is growing continuously. Most features of the specific platelet function in these physiological and pathophysiological phenomena are determined by the complex molecular structure of the cell surface. The outer platelet surface is characterized by a broad spectrum of different receptors and membrane proteins which determine the reactivity of platelets with various agonists and the adhesion to soluble and cell-bound proteins [9]. The different receptors include platelet-specific glycoprotein (GP) complexes which predominantly mediate binding to matrix proteins, such as thrombin, fibrinogen and collagen. Many of the GPs carry human platelet alloantigens (HPA) relevant in clinical platelet immunology [reviewed in 10]. Other receptors are involved in platelet adhesion to other cells (e.g. P-selectin and PECAM-1) or specifically bind agonists of platelet activation (e.g. PAR1 for thrombin and $\mathrm{P}_{2} \mathrm{Y}_{1}$ for ADP). Interestingly, specific receptors and selective transporters of various neurotransmitters, such as serotonin and dopamine, can be found on platelets. Therefore, platelets are used as tools in psychiatric research and as a peripheral model for central serotonergic neurons $[11,12]$. The detailed molecular characterization of the platelet surface including receptors, transporters, channels and other membrane-associated proteins will have a great impact on the understanding of cellular functions that have not yet been described in platelets. Scientists have started to apply the new technologies of transcriptomics and proteomics also to platelet research. A detailed description of proteome techniques including their limitations is given in another article published in this issue [44]. This review integrates pub- lished as well as some unpublished RNA and protein data to address the question of whether RNA data reflect the actual protein expression in platelets. Whole-genome transcriptomic analyses are much easier to perform than complex proteomic approaches, but we should learn more about the significance of RNA data. With a focus on membrane proteins, we examine how transcriptomic and proteomic studies led to the identification of novel platelet proteins, including proteins previously known in other cells but not in platelets as well as socalled hypothetical proteins of unknown function.

\section{Concordance of Platelet Transcriptome and Proteome Data}

Over the past few years, a number of studies have been performed to characterize the platelet transcriptome and proteome [13-20]. All transcriptome studies identified known platelet gene transcripts as well as transcripts not previously described for platelets [13-15]. Leukocyte contamination was minimized either by differential centrifugation and magnetic bead separation [13] or by filtration using leukocyte adhesion filters [14]. The efficacy of leukocyte depletion was demonstrated by flow cytometry [13] or by the absence of PCR signals for genomic DNA or leukocyte-specific gene transcripts (e.g. CD15 or CD45) [14]. Gnatenko et al. [13] and McRedmond et al. [15] used the same microarray platform and published the 50 most abundant genes. The majority of transcripts were shared between the two studies. We used a different microarray platform based on 50mer oligonucleotide probes spotted onto glass slides (30K human array; MWG-Biotech, Ebersberg, Germany) and were able to analyze 28,683 individual human genes [2, unpublished data]. This platelet RNA profiling revealed 5,310 (18.5\%) positive signals. All of the published top 50 platelet transcripts were also positive in our platelet RNA profile (table 1), except for the gene encoding progesterone receptor membrane component 1 (PGRMC1). The corresponding protein was identified in two proteome studies [17, 20].

McRedmond et al. [15] obtained platelet transcriptome and proteome data with a focus on secreted proteins and compared both molecular profiles. The so-called secretome was obtained from the supernatant of platelets after thrombin stimulation and included 82 distinct proteins. For 70 of these proteins, corresponding RNA data was obtained by microarray analysis. The transcriptome data matched 48 proteins (69\%), whereas for the remaining 22 proteins $(31 \%)$ no gene transcript could be detected. Similar results were found when published proteome data were compared to the transcriptome data: 82 (68\%) of 120 platelet proteins identified by O'Neill et al. [17] matched with RNA profiling, and the remaining 38 $(32 \%)$ were absent in the platelet transcriptome. Only 64 of the 122 platelet proteins identified by Marcus et al. [16] were represented by the microarray system used by McRedmond et 
Table 1. Concordance of platelet transcriptome and proteome data

\begin{tabular}{|c|c|c|c|}
\hline Gene description [Gene ID] & $\begin{array}{l}\text { Transcriptome } \\
\text { (reference) }^{\mathrm{a}}\end{array}$ & $\begin{array}{l}\text { Proteome } \\
\text { (reference) }^{\mathrm{b}}\end{array}$ & $\begin{array}{l}\text { Known } \\
\text { protein }^{c}\end{array}$ \\
\hline Coagulation factor XIIIA1 [2162] & $13-15$ & $15,17-19$ & $\mathrm{x}$ \\
\hline Platelet glycoprotein $\mathrm{Ib} \beta$ [2812] & $13-15$ & $15,17,19,20$ & $\mathrm{x}$ \\
\hline Platelet glycoprotein IIb [3674] & 13,14 & $17-20$ & $\mathrm{x}$ \\
\hline$\beta$-2-microglobulin [567] & $13-15$ & $15,18,19$ & $\mathrm{x}$ \\
\hline Clusterin [1191] & $13-15$ & $15,17,19$ & $\mathrm{x}$ \\
\hline Gelsolin [2934] & 14 & $18-20$ & $\mathrm{x}$ \\
\hline Osteonectin (SPARC) [6678] & $13-15$ & $15,17,19$ & $\mathrm{x}$ \\
\hline Platelet factor 4 (PF4) [5196] & $13-15$ & $15,18,19$ & $\mathrm{x}$ \\
\hline Vinculin [7414] & 14,15 & $18-20$ & $\mathrm{x}$ \\
\hline Glutathione peroxidase 1 (GPX1) [2876] & $13-15$ & 19,20 & $\mathrm{x}$ \\
\hline HLA-C [3107] & 13,15 & 19,20 & $\mathrm{x}$ \\
\hline Syntaxin $4[6810]$ & 14 & 18,20 & $\mathrm{x}$ \\
\hline adhesion glycoprotein DNAM-1 (CD226) [10666] & 14 & 20 & $\mathrm{x}$ \\
\hline Thymosin $\beta 4$ [7114] & $13-15$ & 15 & $\mathrm{x}$ \\
\hline Transgelin 2 [8407] & $13-15$ & $15,18-20$ & - \\
\hline Breast cancer associated protein 1 (BRAP1) [51411] & 14 & 18,19 & - \\
\hline Neurogranin [4900] & $13-15$ & $1^{\mathrm{d}}$ & - \\
\hline Progesterone membrane component 1 (PGRMC1) [10857] & 13,15 & 17,20 & - \\
\hline Regulator of G-protein signalling (RGS10) [6001] & 13,14 & 18 & - \\
\hline Regulator of G-protein signalling (RGS20) [8601] & 14 & 19 & - \\
\hline Ferritin heavy chain 1 [2495] and light chain 1 [2512] & $13-15$ & & - \\
\hline HLA-E [3133] & $13-15$ & & - \\
\hline Integrated membrane protein MIC2 (CD99) [4267] & $13-15$ & & - \\
\hline Nuclear receptor coactivator 4 (NCOA4) [8031] & $13-15$ & & - \\
\hline Ornithine decarboxylase antizyme (OAZ1) [4946] & $13-15$ & & - \\
\hline Ubiquitin C [7316] & $13-15$ & & - \\
\hline MutL homolog 3 [27030] & 13,15 & & - \\
\hline $\begin{array}{l}\text { aThe top } 50 \text { most abundant gene transcripts published in }[13 \\
\text { by our group [14, unpublished data]. } \\
\text { bProteomic data published in [15] and [17-20] were conside } \\
\text { cPlatelet proteins known from previous studies. } \\
\text { d The neurogranin protein was identified by Western blot an }\end{array}$ & [15] are consider & 1 as the positive & dentified \\
\hline
\end{tabular}

al. [15] Among these, protein and RNA expression matched in 44 cases $(69 \%)$. We compared our transcriptome data with the to date largest platelet proteomic study [19] which comprised 641 distinct proteins. As an example, among the 69 identified transmembrane proteins, 60 corresponding genes were represented on our microarrays. In 40 cases $(67 \%)$ the RNA signal was positive and confirmed the proteome findings.

Generally, two thirds of platelet proteins identified by complex proteomics can also be detected as corresponding gene transcript by RNA microarray analysis. Thus, when screening for protein expression via a transcriptomic approach, one can expect false-negative results for about one third of the genes. This may be due to i) the limited mRNA stability of these genes, ii) the fact that the level of RNA expression does not correlate with the level of protein expression and the possibility that very low levels of RNA are not detected by microarray analysis, iii) the fact that some proteins may be preformed in megakaryocytes and stored at an earlier stage resulting in mRNA degradation, iv) the fact that proteins are not synthesized by megakaryocytes or platelets but are taken up from plasma or other cells. Especially in platelets where due to the lack of nuclear gene transcription the transcriptome is not dynamic, the stability of mRNA species has a significant impact. It may be concluded that the platelet transcriptome represents the most stable transcripts of genes active during late megakaryopoiesis.

A considerable number of mRNA species have not yet been detected by proteomics. For 22 of the 50 most abundant platelet transcripts $[13,15]$ no corresponding protein has been described by proteomics or classical approaches of protein identification. Interestingly, 7 gene transcripts were identified encoding distinct histones (e.g. H2A histone family members A, L, O and Q). Histones are usually located in the cell nucleus in association with DNA, and therefore it seems unlikely that these proteins can be found in platelets. Another example is ferritin for which mRNA encoding the heavy chain and the light chain has been identified at high levels in all transcriptome studies [13-15]. None of the proteome studies could confirm the abundance of ferritin. Only one report about the detection of low ferritin levels in platelets (measured by ra- 
dioimmunoassay) exists in the literature [21]. Further genes identified by transcriptomics but not by proteomics are given in table 1 . These findings are probably due to the lack of translation of these transcripts, but may also result from special structural or biochemical characteristics that make these proteins difficult to identify by complex proteomic approaches. For example, mRNA encoding dynein is unambiguously present in platelets [13-15], and the functional protein was identified [22]. None of the published platelet proteomes obtained by different techniques - gel-based [16-18, 20] and nongelbased $[15,19]$ - included dynein and thus failed to detect this protein. The same holds true for the adrenergic receptors which are important for platelet function. Despite a reasonable copy number of these receptors none of them can be found in the published platelet proteomes. Platelets contain mRNA species which are obviously not translated to the encoded protein. The number of such gene transcripts is difficult to estimate because a lack of protein data may also represent limitations of the methodology used. In summary, by using a transcriptomic approach to identify novel proteins, about one third of false-negative results can be expected. The number of false-positive results remains uncertain. If a gene of interest is positive at the RNA level, different methods should be used to demonstrate the corresponding protein. Proteomic approaches directly detect the gene products but are more complex to perform and methodology limitations exist as well.

\section{RNA and Protein Data of Known and Novel Platelet Receptors}

As mentioned above, the characterization of membrane proteins at the platelet surface is of special interest for a number of reasons: i) identification of novel platelet alloantigens (impact on platelet immunology), ii) identification of adhesion molecules (impact on hemostasis and inflammation) and iii) identification of signaling receptors (impact on platelet agonism). Whole-genome screening for novel platelet membrane proteins by transcriptomics requires less time and effort compared to proteomics but entails limitations concerning significance of data. The platelet transcriptome revealed a significantly higher number of positive receptor and other membrane proteins compared to other functional gene categories [14]. The most abundant transcripts from different functional categories of membrane proteins revealed several interesting findings (table 2). Among the 10 most abundant cytokine receptor-specific RNAs, 4 encode interleukin receptors: IL-6R, IL-10R, IL-11R and IL-12R. These receptors have not yet been described for platelets. By performing Western blot analysis and flow cytometry with specific monoclonal antibodies, we investigated 3 of these receptors and could demonstrate IL-10R and IL-12R expression on platelets (IL-6R was not detected) (unpublished data). The chemokine receptor 5 (CCR5) gene transcript is highly abundant in platelets, but ac- cording to published data, the protein is absent in platelets [23]. We used 2 different monoclonal antibodies and were able to detect the protein with one of them [24]. Furthermore, the platelet transcriptome revealed a number of highly abundant mRNAs encoding neuronal receptors and transporters (e.g. for GABA, serotonin or neurotensin). Further investigations will be undertaken to demonstrate the expression of certain neuronal receptors on platelets. Nicotinic acetylcholine receptors have been identified on endothelial cells [25]. In platelets, one of the most abundant gene transcripts encodes the nicotinic acetylcholine receptor $\alpha$ polypeptide 10 (CHRNA10). If the receptor protein is expressed on platelets, this would represent a further example of similar receptor expression of endothelial cells and platelets already known for P-selectin, PECAM-1, PAR-1 and others.

In a recent study, Moebius et al. [20] investigated the platelet proteome using a gel-based approach optimized for membrane proteins. Among the 297 identified distinct proteins, 84 $(28.3 \%)$ are known to be located in or closely associated with the plasma membrane. Many of them represented known platelet receptors, such as GPs, integrins, P-selectin and PECAM-1. The membrane proteome included several interesting new findings. For example, in addition to the syntaxins 4 and 7 known to be involved in vesicle trafficking in platelets $[26,27]$, the syntaxins 6 and 11 were identified. SEC22B and VAMP-A represent further vesicle-associated proteins demonstrated in platelets for the first time. These new proteins could also be detected in the platelet transcriptome [14]. Intercellular junctional proteins, such as JAM, are known to be expressed on platelets [reviewed in 28]. Proteome studies confirmed the expression of JAM-A and JAM-C and added information about further structural components of junctions, such as pannexin 1 and the PDZ/LIM domain protein 1 [19, 20]. RGS10, RGS19, RGS20 and STIM1 are signaling receptors described in the platelet proteome and presumed to be located in the plasma membrane. Two signaling molecules, RGS10 and RGS18, were identified in a differential proteome analysis [29]. Both, the transcriptomic and the proteomic approach yielded proteins presumably located in the plasma membrane and not described in platelets before.

\section{Hypothetical Proteins with Transmembrane Features}

The proteome study of platelet membranes [20] revealed novel potential receptors, such as the hypothetical proteins MGC5508, KIAA0747 and FLJ11036 (table 3). Computer analysis of the protein sequence revealed characteristic transmembrane domains (TMDs) for these proteins. The hypothetical proteins identified by Martens et al. [19] included 4 proteins with at least one TMD: KIAA0152, similar to RIKEN cDNA F30003B03 and 9430029K10, and a protein similar to integrin $\beta 1$ according to BLAST search (table 3 ). Three of the proteins (KIAA0747, FLJ11036, 9430029K10) could also be 
Table 2. The strongest RNA signals in platelets from different membrane protein categories obtained by microarray hybridization analysis [14, unpublished data]

\begin{tabular}{|c|c|}
\hline Gene description [Gene ID] ${ }^{\mathrm{a}}$ & $\begin{array}{l}\text { RNA signal intensity } \\
(\mathrm{MFI} \pm \mathrm{SD})\end{array}$ \\
\hline \multicolumn{2}{|l|}{ Cell adhesion molecules/integrins } \\
\hline Putative neuronal cell adhesion molecule (PUNC) [9543] & $31,410.7 \pm 18,013.5$ \\
\hline Down syndrome cell adhesion molecule (DSCAM) [1826] & $27,666.3 \pm 4,351.2$ \\
\hline$>$ Glycoprotein Ib $\beta$ polypeptide precursor $(G P 1 B B)$ [2812] & $24,995.7 \pm 20,525.5$ \\
\hline Integrin $\beta 7$ (ITGB7) [3695] & $23,834.8 \pm 14,653.4$ \\
\hline Herstatin-2, 68 kD secreted autoinhibitor glycoprotein (HER2) [2064] & $21,958.8 \pm 1,461.4$ \\
\hline Pregnancy specific $\beta$-1-glycoprotein 4 (PSG4) [5672] & $21,688.2 \pm 6,641.9$ \\
\hline Glycoprotein A repetitions predominant precursor (GARP) [2615] & $21,594.7 \pm 10,885.7$ \\
\hline Clusterin (CLU) [1191] & $20,553.2 \pm 21,511.8$ \\
\hline$>$ Adhesion glycoprotein DNAM-1 (CD226) [10666] & $18,652.5 \pm 6,610.3$ \\
\hline \multicolumn{2}{|l|}{ Cytokine/chemokine/growth factor receptors } \\
\hline Interleukin 12 receptor $\beta 2$ (IL-12RB2) [3595] & $23,891.0 \pm 23,507.4$ \\
\hline Interleukin receptor (IL-6R) [3570] & $18,300.1 \pm 18,713.3$ \\
\hline Interleukin 11 receptor $\alpha$ (IL-11RA) [3590] & $15,561.8 \pm 7,256.6$ \\
\hline Erythropoietin receptor precursor (EPOR) [2057] & $15,430.3 \pm 9,390.0$ \\
\hline Epidermal growth factor receptor (EGFR) [1956] & $14,233.4 \pm 11,805.4$ \\
\hline Chemokine (c-c motif) receptor 5 (CCR5) [1234] & $13,912.9 \pm 4,008.2$ \\
\hline Niacin receptor, GTP-binding protein (HM74) [8843] & $11,968.5 \pm 6,396.8$ \\
\hline Fibroblast growth factor receptor 1, isoform 9 precursor (FGFR1) [2260] & $11,456.4 \pm 5,967.1$ \\
\hline Platelet-derived growth factor receptor $\alpha$ (PDGFRA) [5156] & $10,102.3 \pm 5,375.1$ \\
\hline Interleukin 10 receptor $\alpha$ (IL-10RA) [3587] & $9,328.6 \pm 3,620.0$ \\
\hline \multicolumn{2}{|l|}{ Neuronal receptors } \\
\hline Nicotinic acetylcholin receptor $\alpha$ polypeptide 10 (CHRNA10) [57053] & $40,486.9 \pm 15,096.5$ \\
\hline Neurotensin receptor 1 (NTSR1) [4923] & $32,884.8 \pm 15,240.2$ \\
\hline Purinergic receptor P2Y, G-protein coupled 11 (P2RY11) [5032] & $23,479.8 \pm 7,256.7$ \\
\hline$>\alpha$-1B-adrenergic receptor (ADRA1B) [147] & $21,508.9 \pm 4,911.1$ \\
\hline Gamma-aminobutyric acid (GABA) A receptor $\gamma 3$ (GABRG3) [2567] & $17,761.4 \pm 3,699.5$ \\
\hline$>\alpha$-1A-adrenergic receptor isoform 1 (ADRA1A) [148] & $15,538.6 \pm 8,845.7$ \\
\hline$>$ Adrenergic $\beta$-3-receptor (ADRB3) [155] & $12,554.6 \pm 5,130.3$ \\
\hline Gamma-aminobutyric acid (GABA) A receptor $\delta$ (GABRD) [2563] & $12,526.6 \pm 9,493.0$ \\
\hline$>$ 5-hydroxytryptamine (serotonin) receptor 3B (HTR3B) [9177] & $7,903.8 \pm 4,747.9$ \\
\hline$>$ Glutamate receptor metabotropic 1 (GRM1) [2911] & $7,524.1 \pm 4,061.5$ \\
\hline
\end{tabular}

Table 2 continued on next page found in the transcriptome [14]. The whole-genome screening of the platelet transcriptome included 3,579 genes encoding hypothetical proteins. Among these, 741 (20.7\%) revealed a positive RNA signal. The 250 most strongly expressed genes were further investigated in-silico for the encoded protein sequences. The polypeptides deduced from 112 (44.8\%) of the 250 genes were less than 200 amino acids in length. These were not considered for further investigation because it is unlikely that short proteins represent functional receptors. Of the remaining 138 hypothetical proteins, 51 (36.9\%) proved to be known proteins, or the data file of the hypothetical protein was replaced by a data file of a known protein. In addition, 65 proteins $(47.1 \%)$ showed significant similarity to proteins with known function, of which 20 represented transmembrane proteins (e.g. TMEM38A and TMEM25). The remaining 22 hypothetical proteins $(16.0 \%)$ revealed no significant similarity to any known protein sequence in the databases. These polypeptide sequences were further analyzed in-silico by com- puting the hydrophobicity (Kyte-Doolittle plot, [30]), determining the grand average of hydropathicity (GRAVY) value [31] and the predicting TMDs [32]. Of these proteins, 6 revealed hydrophobic regions and TMDs typical for transmembrane proteins (table 3). The 459 amino acid protein MGC9564 is composed of large hydrophobic regions (11 TMDs) with the highest GRAVY value (0.597) among all proteins analyzed. FLJ20297 and FIBCD1 are typical membraneanchored proteins each with a single TMD at the C- and the $\mathrm{N}$-terminal end, respectively, and negative GRAVY values. Major parts of both proteins were predicted to be located outside of the cell.

Generally, the data concerning hypothetical proteins is very similar to that of other gene categories, i.e. proteins can be found in both the platelet transcriptome and proteome or only in one of the two molecular profiles. The putative membrane proteins identified exclusively in the transcriptome represent encouraging candidates for further experimental investigation. 


\begin{tabular}{|c|c|}
\hline Gene description $[\text { Gene ID }]^{a}$ & $\begin{array}{l}\text { RNA signal intensity } \\
(\mathrm{MFI} \pm \mathrm{SD})\end{array}$ \\
\hline \multicolumn{2}{|l|}{ Transporters/channels } \\
\hline Solute carrier family 20 (phosphate transporter) member 2 (SLC20A2) [6575] & $61,815.8 \pm 8,748.2$ \\
\hline Solute carrier family sodium bicarbonate transporter member 11 (SLC4A11) [83959] & $51,767.0 \pm 17,119.2$ \\
\hline$>$ Calcium activated chloride channel 4 (CLCA4) [22802] & $35,523.4 \pm 28,601.5$ \\
\hline Epithelial calcium channel 2 (TRPV6) [55503] & $33,012.6 \pm 17,826.2$ \\
\hline$>$ Calcium channel, voltage-dependent, g subunit 2 (CACNG2) [10369] & $26,147.2 \pm 8,265.3$ \\
\hline Solute carrier family 13 (dicarboxylate transporter) member 2 (SLC13A2) [9058] & $24,592.7 \pm 11,502.9$ \\
\hline$>$ Chloride channel 6, isoform CLC-6A (CLCN6) [1185] & $23,342.3 \pm 7,224.7$ \\
\hline Tetracycline transporter-like protein (TETRAN) [10227] & $19,913.4 \pm 8,374.9$ \\
\hline Potassium large conductance calcium-activated channel (KCNMA1) [3778] & $19,292.3 \pm 4,477.0$ \\
\hline Putative acid-sensing ion channel (ASIC4) [55515] & $17,062.5 \pm 6,047.7$ \\
\hline \multicolumn{2}{|l|}{ Hormone receptors } \\
\hline$>$ Adrenomedullin receptor (ADMR) [11318] & $20,030.8 \pm 10,596.5$ \\
\hline Angiotensin receptor-like 1 (AGTRL1) [187] & $19,491.2 \pm 5,807.8$ \\
\hline Melanocortin 3 receptor (MC3R) [4159] & $16,728.7 \pm 6,212.1$ \\
\hline Histamine receptor h3 (HRH3) [11255] & $13,434.3 \pm 6,328.0$ \\
\hline$>$ Angiotensin receptor 1 (AGTR1) [185] & $11,078.1 \pm 6,550.0$ \\
\hline Melanocortin 1 receptor (MC1R) [4157] & $10,224.3 \pm 7,228.4$ \\
\hline$>$ Prostaglandin E receptor 1 (subtype EP1), 42kd (PTGER1) [5731] & $7,767.7 \pm 3,932.4$ \\
\hline Thyroid hormone receptor $\alpha 1$ (THRA1) [7067] & $7,181.9 \pm 670.0$ \\
\hline Anti-mullerian hormone receptor type II (AMHR2) [269] & $6,852.8 \pm 3,097.7$ \\
\hline$>$ Estrogen receptor 1 (ESR1) [2099] & $6,428.2 \pm 1,104.3$ \\
\hline \multicolumn{2}{|l|}{ Olfactory receptors } \\
\hline Olfactory receptor family 10 , subfamily $\mathrm{H}$, member $2(\mathrm{OR} 10 \mathrm{H} 2)[26538]$ & $26,798.2 \pm 18,286.8$ \\
\hline Olfactory receptor family 7, subfamily A, member 17 (OR7A17) [26333] & $14,481.7 \pm 8,704.2$ \\
\hline Olfactory receptor family 1 , subfamily A, member 1 (OR1A1) [8383] & $12,292.6 \pm 2,695.5$ \\
\hline Putative olfactory receptor (TPCR106) [158131] & $7,970.3 \pm 918.9$ \\
\hline Olfactory receptor family 3, subfamily A, member 2 (OR3A2) [4995] & $6,836.0 \pm 2,707.3$ \\
\hline Olfactory receptor family 2, subfamily C, member 1 (OR2C1) [4993] & $5,395.1 \pm 2,938.6$ \\
\hline Olfactory receptor family 1 , subfamily D, member 5 (OR1D5) [8386] & $4,662.7 \pm 1,561.3$ \\
\hline
\end{tabular}

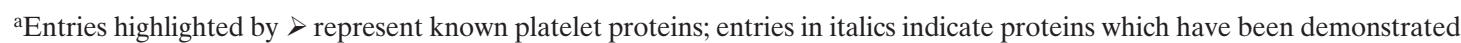
by proteome studies.

$\mathrm{MFI}=$ Mean fluorescence intensity, $\mathrm{SD}=$ standard deviation.

Table 3. Structural features of putative membrane proteins identified in the platelet transcriptome [14] and/or proteome $[19,20]$

\begin{tabular}{llrllc}
\hline Name of hypothetical protein & $\begin{array}{l}\text { Predicted } \\
\text { TMDs, } \mathrm{n}\end{array}$ & GRAVY & $\begin{array}{l}\text { Present in } \\
\text { transcriptome }\end{array}$ & $\begin{array}{l}\text { Present } \\
\text { in proteome }\end{array}$ & Reference \\
\hline TMEM40 (FLJ11036) & 2 & -0.453 & $\mathrm{x}$ & $\mathrm{x}$ & 20 \\
KIAA0747 & 2 & -0.222 & $\mathrm{x}$ & $\mathrm{x}$ & 20 \\
Similar to RIKEN cDNA 9430029K10 & 4 & 0.331 & $\mathrm{x}$ & $\mathrm{x}$ & 19 \\
Similar to RIKEN cDNA F730003B03 & 8 & -0.146 & - & $\mathrm{x}$ & 19 \\
MGC5508 & 4 & 0.541 & - & $\mathrm{x}$ & 20 \\
KIAA0152 & 1 & -0.097 & - & $\mathrm{x}$ & 19 \\
MGC9564 (LOC113235) & 11 & 0.597 & $\mathrm{x}$ & - & - \\
BC002942 (LOC91289) & 6 & 0.055 & $\mathrm{x}$ & - & - \\
MGC12992 (LOC84302) & 3 & -0.043 & $\mathrm{x}$ & - & - \\
FLJ20507 (LOC55654) & 3 & 0.140 & $\mathrm{x}$ & $\mathrm{x}$ & \\
FLJ20297 (LOC55627) isoform 1 & 1 & -0.094 & $\mathrm{x}$ & $\mathrm{x}$ & \\
Fibrinogen C domain containing 1 (FIBCD1) & 1 & -0.436 & $\mathrm{x}$ & - \\
\hline
\end{tabular}

TMDs = Transmembrane domains predicted by computer analysis [32]; GRAVY = grand average of hydropathicity (positive GRAVY values indicate hydrophobic proteins, negative GRAVY values indicate hydrophilic proteins [31]). 
These proteins may be identified by using specific immunological approaches instead of proteomic screening due to the limitations of these methods concerning membrane-anchored proteins.

\section{Conclusion}

Integration of platelet transcriptomes and proteomes demonstrated that some limitations exist regarding the significance of RNA data. On the other hand, transcriptome analysis via microarray hybridization is easier to perform compared to the complex proteome techniques. The significant limitations of the various proteomic methods, especially concerning hydrophobic proteins, protein glycosylation or proteins with tight folding, have been recognized and were discussed in a recent report of the ISTH Platelet Physiology Subcommittee $[33,34]$. Protein glycosylation and the identification of glycoprotein isoforms was achieved in a proteomic approach in which lectin affinity chromatography as well as chemical trap- ping of protein-bound oligosaccharides was applied [35]. Thus, the limitations of current proteomic methods might be solved in future. In conclusion, RNA profiling represents a suitable approach for identification of novel gene functions in platelets. Comparative profiling (e.g. patients vs. healthy individuals) is definitely appropriate for the identification of genes associated with platelet disorders. This has already been proven [8, 36] and was discussed in a recent review [37].

Views still differ regarding the biological role of gene transcripts in terms of de novo protein biosynthesis in platelets. A number of studies showed newly synthesized proteins after platelet stimulation [38-40], but it was also shown that de novo synthesis of cytokines in platelet preparations is strongly correlated with the amount of leukocyte contamination [41, 42]. Recently, active spliceosomes were identified in the cytoplasm of megakarycytes and platelets [43]. The signal-dependent splicing of pre-mRNA indicated regulation of protein biosynthesis in platelets. In our opinion, the impact of active spliceosomes on the function of circulating platelets is still uncertain.

\section{References}

1 McEver RP: P-selectin/PSGL-1 and other interactions between platelets, leukocytes, and endothelium; in Michelson AD (ed): Platelets. San Diego, CA, Academic Press/Elsevier Science, 2002, pp 139-155.

2 Lösche W: Platelets and tissue factor. Platelets 2005;16:313-319.

3 Bruce IJ, Kerry R: The effect of chloramphenicol and cycloheximide on platelet aggregation and protein synthesis. Biochem Pharmacol 1987;36: 1769-1773.

- 4 Weyrich AS, Dixon DA, Pabla R, Elstad MR, McIntyre TM, Prescott SM, Zimmerman GA: Signal-dependent translation of a regulatory protein, Bcl-3, in activated human platelets. Proc Natl Acad Sci U S A 1998;95:5556-5561.

5 Hartwig D, Härtel C, Hennig H, Müller-Steinhardt M, Schlenke P, Klüter H: Evidence for de-novosynthesis of cytokines and chemokines in platelet concentrates. Vox Sang 2002;82:182-190.

6 Dugrillon A, Dobrowolski C, Lösel R, Klüter H, Bugert P: Lack of protein biosynthesis in leukocyte-depleted platelet preparations. Platelets 2004; 15:239-240.

7 Macaulay IC, Carr P, Farrugia R, Watkins NA: Analysing the platelet transcriptome. Vox Sang 2004;87(suppl 2):S42-S46.

$\checkmark 8$ Gnatenko DV, Cupit LD, Huang EC, Dhundale A, Perrotta PL, Bahou WF: Platelets express steroidogenic 17 beta-hydroxysteroid dehydrogenases. Distinct profiles predict the essential thrombocythemic phenotype. Thromb Haemost 2005;94:412-421.

9 Clemetson KJ: Platelet receptors; in Michelson AD (ed): Platelets. San Diego, CA, Academic Press/Elsevier Science, 2002, pp 65-84.

10 Metcalfe P, Watkins NA, Ouwehand WH, Kaplan C, Newman P, Kekomaki R, de Haas M, Aster R, Shibata Y, Smith J, Kiefel V, Santoso S: Nomenclature of human platelet antigens (HPA). Vox Sang 2003;85:240-45.

11 Camacho A, Dimsdale JE: Platelets and psychiatry: lessons learned from old and new studies. Psychosom Med 2000;62:326-336.
12 Rausch JL, Johnson ME, Li J, Hutcheson J, Carr BM, Corley KM, Gowans AB, Smith J: Serotonin transport kinetics correlated between human platelets and brain synaptosomes. Psychopharmacology 2005;180:391-398.

13 Gnatenko DV, Dunn JJ, McCorkle SR, Weissmann D, Perrotta PL, Bahou WF: Transcript profiling of human platelets using microarray and serial analysis of gene expression. Blood 2003;101:2285-2293.

14 Bugert P, Dugrillon A, Günaydin A, Eichler H, Klüter H: Messenger RNA profiling of human platelets by microarray hybridization. Thromb Haemost 2003;90:738-748.

15 McRedmond JP, Park SD, Reilly DF, Coppinger JA, Maguire PB, Shields DC, Fitzgerald DJ: Integration of proteomics and genomics in platelets: a profile of platelet proteins and platelet-specific genes. Mol Cell Proteomics 2004;3:133-144.

16 Marcus K, Immler D, Sternberger J, Meyer HE: Identification of platelet proteins separated by twodimensional gel electrophoresis and analyzed by matrix assisted laser desorption/ionization-time of flight-mass spectrometry and detection of tyrosinephosphorylated proteins. Electrophoresis 2000;21: 2622-2636.

17 O'Neill EE, Brock CJ, von Kriegsheim AF, Pearce AC, Dwek RA, Watson SP, Hebestreit HF: Towards complete analysis of the platelet transcriptome. Proteomics 2002;2:288-305.

18 Garcia A, Prabhakar S, Brock CJ, Pearce AC, Dwek RA, Watson SP, Hebestreit HF, Zitzmann N: Extensive analysis of the human platelet proteome by two-dimensional gel electrophoresis and mass spectrometry. Proteomics 2004;4:656-668.

19 Martens L, Van Damme P, Van Damme J, Staes A, Timmermann E, Ghesquiere B, Thomas GR, Vandekerckhove J, Gevaert K: The human platelet proteome mapped by peptide-centric proteomics: a functional protein profile. Proteomics 2005;5: 3193-3204.
20 Moebius J, Zahedi RP, Lewandrowski U, Berger C, Walter U, Sickmann A: The human platelet membrane proteome reveals several new potential membrane proteins. Mol Cell Proteomics 2005;4: 1754-61.

21 Sebestik V: Ferritin content in human thrombocytes. Acta Univ Carol [Med] (Praha) 1989;35: 175-177.

22 Rothwell SW, Calvert VS: Activation of human platelets causes post-translational modifications to cytoplasmic dynein. Thromb Haemost 1997;78: 910-918.

23 Clemetson KJ, Clemetson JM, Proudfoot AE, Power CA, Baggiolini M, Wells TN: Functional expression of CCR1, CCR3, CCR4, and CXCR4 chemokine receptors on human platelets. Blood 2000;96:4046-4054.

24 Bugert P, Dugrillon A, Klüter H: Identification of novel receptors on platelets. Transfus Med Hemother 2004;31(suppl 3):S21.

25 Macklin KD, Maus AD, Pereira EF, Albuquerque EX, Conti-Fine BM: Human vascular endothelial cells express functional nicotinic acetylcholine receptors. J Pharmacol Exp Ther 1998;287:435-439.

26 Lemons PP, Chen D, Bernstein AM, Bennett MK, Whiteheart SW: Regulated secretion in platelets: identification of elements of the platelet exocytosis machinery. Blood 1997;90:1490-1500.

27 Chen D, Bernstein AM, Lemons PP, Whiteheart SW: Molecular mechanisms of platelet exocytosis: role of SNAP-23 and syntaxin 2 in dense core granule release. Blood 2000;95:921-929.

28 Bazzoni G: The JAM family of junctional adhesion molecules. Curr Opin Cell Biol 2003;15:525-530.

29 Garcia A, Prabhakar S, Hughan S, Anderson TW, Brock CJ, Pearce AC, Dwek RA, Watson SP, Hebestreit HF, Zitzmann N: Differential proteome analysis of TRAP-activated platelets: involvement of DOK-2 and phosphorylation of RGS proteins. Blood 2004;103:2088-2095.

30 http://bioinformatics.weizmann.ac.il/hydroph.

31 www.expasy.org/tools/protparam.html. 
32 www.cbs.dtu.dk/services/TMHMM.

33 Dittrich M, Birschmann I, Stuhlfelder C, Sickmann A, Herterich S, Nieswandt B, Walter U, Dandekar T. Understanding platelets. Lessons from proteomics, genomics and promises from network analysis. Thromb Haemost 2005;94:916-925.

34 Watson SP, Bahou WF, Fitzgerald D, Ouwehand W, Rao AK, Leavitt AD: ISTH Platelet Physiology Subcommittee: Mapping the platelet proteome: a report of the ISTH Platelet Subcommittee. J Thromb Haemost 2005;3:2098-2101.

35 Lewandrowski U, Moebius J, Walter U, Sickmann A: Elucidation of N-glycosylation sites on human platelet proteins: a glycoproteomic approach. $\mathrm{Mol}$ Cell Proteomics 2006;5:226-233.

36 Hyman T, Huizing M, Blumberg PM, Falik-Zaccai TC, Anikster Y, Gahl WA: Use of a cDNA microarray to determine molecular mechanisms involved in grey platelet syndrome. Br J Haematol 2003;122:142-149.
37 Macaulay IC, Carr P, Gusnanto A, Ouwehand WH, Fitzgerald D, Watkins NA: Platelet genomics and proteomics in human health and disease. J Clin Invest 2005;115:3370-3377.

38 Kieffer N, Guichard J, Farcet JP, Vainchenker W, Breton-Gorius J: Biosynthesis of major platelet proteins in human blood platelets. Eur J Biochem 1987;164:189-195.

39 Weyrich AS, Dixon DA, Pabla R, Elstad MR, McIntyre TM, Prescott SM, Zimmerman GA: Signal dependent translation of regulatory protein, Bcl-3, in activated human platelets. Proc Natl Acad Sci U S A 1998;95:5556-5561.

40 Lindemann S, Tolley ND, Dixon DA, McIntyre TM, Prescott SM, Zimmerman GA, Weyrich AS: Activated platelets mediate inflammatory signaling by regulated interleukin $1 \beta$ synthesis. J Cell Biol 2001;154:485-490.
41 Christensen LL, Grunnert N, Rüdiger N: Comparison of the level of cytokine mRNA in buffy coatderived platelet concentrates prepared with or without white cell reduction by filtration. Transfusion 1998;38:236-241.

42 Hartwig D, Hartel C, Hennig H, Muller-Steinhard M, Schlenke P, Kluter H: Evidence for de-novosynthesis of cytokines and chemokines in platele concentrates. Vox Sang 2002;82:182-190.

43 Denis MM, Tolley ND, Bunting M, Schwertz H, Jiang H, Lindemann S, Yost CC, Rubner FJ, Albertine KH, Swoboda KJ, Fratto CM, Tolley E, Kraiss LW, McIntyre TM, Zimmerman GA, Weyrich AS Escaping the nuclear confines: signal-dependent pre-mRNA splicing in anucleated platelets. Cell 2005;122:379-391.

44 Moebius J, Zahedi R-P, Sickmann A: Platelet proteomics: essentials for understanding and application. Transfus Med Hemother 2006;33:227-235. 